\title{
Trends in Federal Spending: 1955-86
}

\author{
KEITH M. CARLSON
}

$\mathrm{T}$

HE Reagan administration has embarked on an ambitious program to slow the growth of federal spending, a program that is part of an overall economic plan to reduce inflation and promote sustainable economic growth. The purpose of slowing the growth of federal outlays in the overall program is to shift resources from the public to the private sector.

As of July 15, 1981, the administration had proposed a reduction in the growth of federal outlays over the next five years to a 6.2 percent ammal rate, down from an estimated 12.5 percent annual rate from 1976 to $1981 .{ }^{1}$ The planned slowing in federal spending is especially pronounced in the early years of the projection period. Outlays are projected to grow at only a 4.7 percent rate from 1981 to 1984 , followed by an 8.6 percent rate from 1984 to 1986 . The spending plan is targeted to reduce federal outlays to 18.6 percent of GNP in 1986 from an estimated 23.0 percent in 1981.

A considerable amount of budget discussion is couched in terms of expenditure "cuts." For the most part, however, these spending plans are not cuts at all, but reductions in spending from what they would otherwise be. Thus, iny attempt to assess budget developments and/or the administration program must come to grips with that elusive estimate of what outlays "would otherwise be." The Congressional Budget Office (CBO) has prepared a set of such estimates, which it calls "baseline pro-

All references to years in this article anc to heal years, moless otherwise indicated. jections."2 "The administration's spending plan will be presented in light of these baseline projections.

Any assessment of current developments and future trends, moreover, requires a sense of historical perspective. ${ }^{3}$ Thus, this article reviews the course of federal spending over the last 25 years, focusing on the growth of federal outlays relative to the size of the economy as measured by GNP. Trends in the composition of federal spending by major program category also are simmarized.

\section{PAST TRENDS IN FEDERAL SPLNDING: $1955-80$}

To obtain a sense of historical perspective on federal spending, trends are examined for the pertod 1955 through 1980 . Using 1955 as a starting point removes most of the influence of World War 11 and the Korean War, periods of extensive defense spending, yet the period still includes the Cold wat of the 1950s and the Vietnam War. Excluding all defense buildups is undesirable since political and international conditions will always impinge to some degree on decision-making processes relating to federal spending.

\footnotetext{
Congressional Budget Office, Bascline Budget Projections: Fiscal Tears $1982-1986$ ouly 1981 ).

"The purpose of the article is to describe, rather than ithalyse, federal spending trends. For a discussion of the theoretical basis for valous govemmental activites, sed Rotard A Mesgrave and

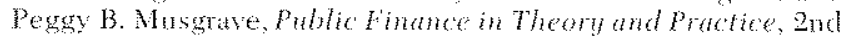
ed. MaGra-Hill Book Company, 1976!. See klso Sam Peltzman, "The Growth of Govemment," The foumal of Letu: and Eronomics (October 1980 , pr. $209-88$.
} 
To review trends in federal spending, it is useful to categorize federal outlays. The Office of Management and Budget develops the budget each year in two fundamental ways: by agency and by function. ${ }^{4}$ These categorizations are important for the budget planning process, but for this article, a smaller number of categories is preferable. The categorm ization chosen is by major program, a categorization used by the CBO.

\section{Explanation of Major Program Categories}

Categorizing federal outlays by major program essentially divides govemment activities into defense and non-defense spending. The latter category is further subdivided according to the form that this spending takes.

Table 1 summarizes the major program categories used as a basis for assessing federal spending trends. National defense consists mainly of the military activities of the Department of Defense. The defense category, however, also includes benefit payments for retired military personnel and Department of Energy programs diverted toward national defense.

In the non-defense category, the largest component consists of benefit payments to individuals.

\footnotetext{
${ }^{4}$ The budget breakdowns used by the Office of Management and Budget are as follows:

$B$ B Asency

I. egislative and judiciai branches

Funds atppropriated to the president

Agriculture

Defense - Mifitary

Defense - Civil

Education

Energy

Health and Human Services

Housing and Unban Development

Interion

Justice

Labor

State

Trinsportation

Treasury

Envirommental Protection Agency

National Aeronatios and Space Administration

Office of persomel management

Veterans administration

Other atgencies

Allowances

Undistributed offsetting receipt:
}

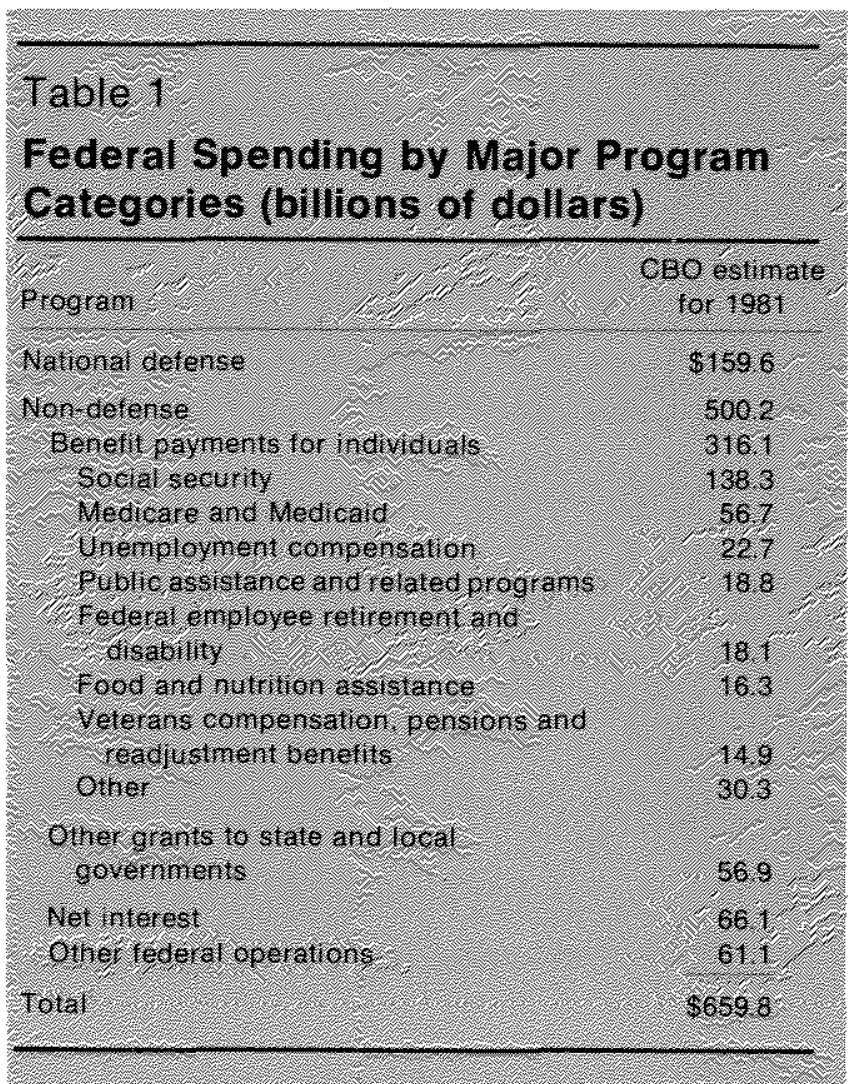

These programs include direct payments from the federal government to individuals (e.g., social security and federal retirement pay) and indirect payments through state and local govermments (e.g., public assistance and child nutrition). Some programs provide cash payments for recipients to use at their discretion, while other programs provide specific services (e.g., Medicare and Medicaid).

Grants to state and local governments, other than benefit payments, include general revenue sharing, the Comprehensive Employment and Training Act, education, community development, highway construction, etc.

Net interest is the interest paid on that portion of the federal debt held by the public. This is a net figure because it excludes interest paid to govermment trust funds that hold government securities, while including interest payments from federal agencies and the public on borrowing from the government

Other federal operations include farm price supports, domestic energy programs, foreign aid, general science research, space technology, etc. In addition, general expenses required to rum the govemment are included in this category. 
Chart?

\section{Federal Budget Outlays as a Percent of GNP}

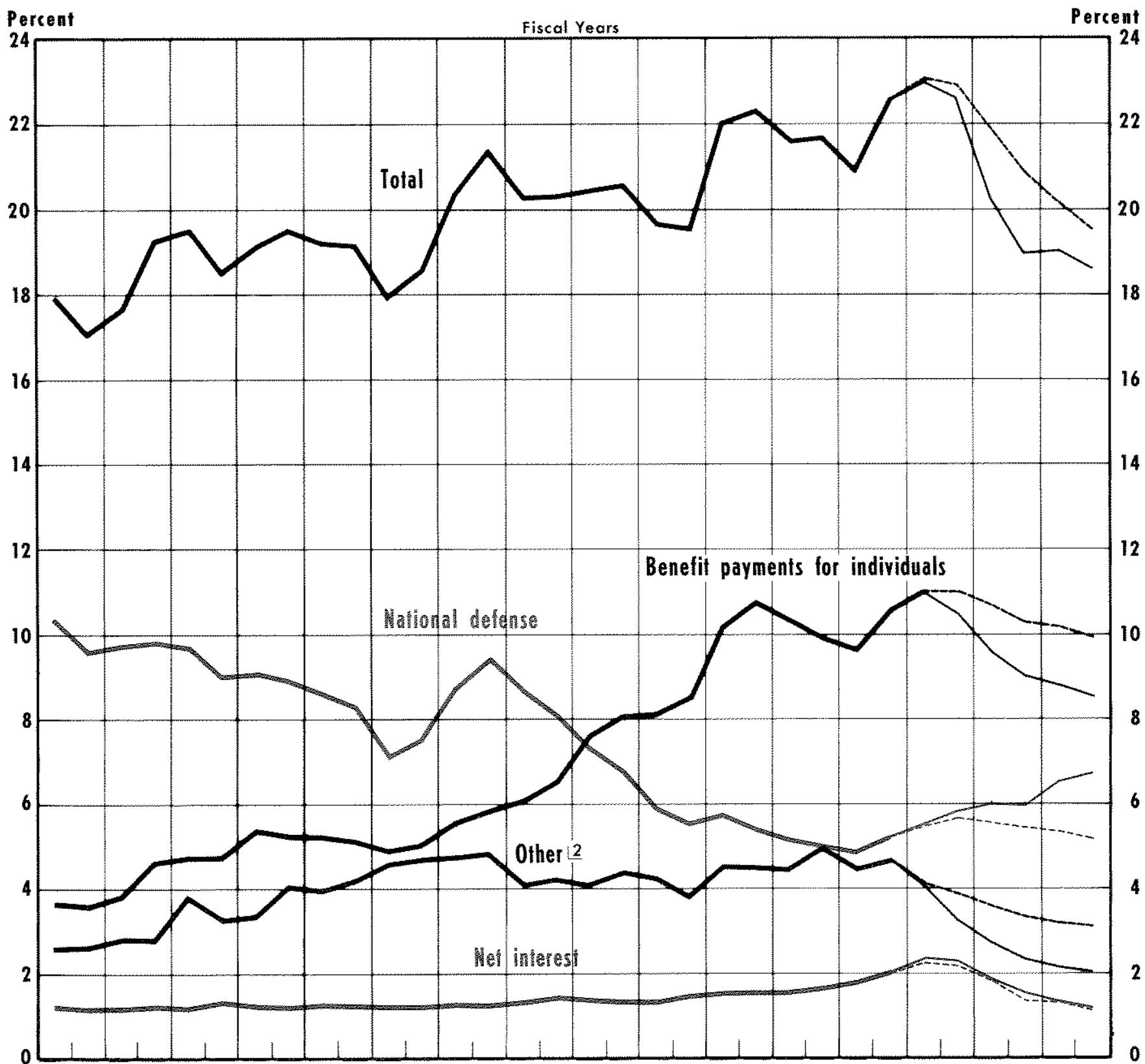

$\begin{array}{llllllllllllllllllllllllllllllll}1955 & 56 & 57 & 58 & 59 & 60 & 61 & 62 & 63 & 64 & 65 & 66 & 67 & 68 & 69 & 70 & 71 & 72 & 73 & 74 & 75 & 76 & 77 & 78 & 79 & 80 & 81 & 82 & 83 & 84 & 85 & 1986\end{array}$

1 Estimates for $1981+1986$ are alternative projections: dashed lines are CBO baseline projections and solid lines are administration projections from Mid-Session Review of the 1982 Budget [July 1981].

2 Other federal operations, plus grants fo state and local governments other than benefit payments for individuals.

\section{Outlays Relative to GNP}

A very useful way to summarize trends in federal spending is to compare them with the growth of
QNP, a comparison that indicates the degree of govermment intervention in the economy. Chart 1 summarizes the historical record by showing total federal outlays and the major program categories as a percent of GNP. 
The trend of total budget outlays relative to GNP has been unmistakably upward during the 1955-80 period, rising from 17.9 percent in 1955 to 22.6 percent in 1980 . This trend has not been smooth, however, in that ontlays relative to GNP have surged in relatively short periods. Though the percentage tends to subside after the surge, it returns to levels higher than prevailed before the surge. The surges during the $1955-80$ period seem to be associated with (1) the $1957-58$ recession and the abbrevinted recovery that followed, (2) the Vietnam War, and (3) the $1973-75$ recession. But the reason outlays as a percent of GNP does not return to pre-surge levels is unclear, except, perhaps, as a result of the momentum of the government spending process.

National defense spending relative to GNP declined throughout 1955-80 except for the period of the Vietnam $W$ ar. In $1955,10.4$ percent of the nation's GNP was directed toward defense outlays, a percentage that declined to 7.2 percent in 1965 , before rising to 9.4 percent during the Vietnam $W_{a r}$ in 1968. Since then, the decline has been dramatic, with the ratio plummeting to 5 percent in 1978 and 1979.

Meanwhile, benefit payments for individuals were only 3.7 percent of GNP in 1955 with social security accounting for 31.4 percent of the total. With a major surge in the $1967-76$ period, benefit payments hit 10.6 percent of GNP in 1980 as social security rose to 43,2 percent of the total. Given the decline in national defense, the bulk of the relative rise in total ontlays over the $1955-80$ period is attributable to the sharp increase in benefit payments to individuals.

The remaining major program categories, though relatively small, show some trends. Net interest was virtually constant at 1.3 percent of GNP fiom 1955 to 1968. Since then, the trend has been upward as the government rums continuous deficits and interest rates keep rising. Net interest reached 2.0 percent of GNP in 1980 .

Other grants to state and local governments, the smallest category in 1955, has been trending upward throughout the period (not shown se parately in chart 1). Starting at 0.4 percent of GNP in 1955 , these grants rose to 2.2 percent in 1980 .

All other outlays relative to GNP, a residual component of the total, changed little on balance from 1955 to 1980 .

More recently, from 1975 to 1980 , federal spend- ing has grown only slightly faster than GNP. Total outlays averaged 22.6 percent of GNP in 1980 , with the decline in defense offset by an upward creep in non-defense categories.

\section{Program Cabegories Relative to Total Outays}

Another way of looking at federal spending is to examine the composition of total outlays. Using the same program categories as before, chart 2 summarizes the composition of federal outlays for $1955-80$.

Chart 2 shows the changing composition of budget outlays more dramatically than chat 1 , though the same basic data are used in the construction of both. The sharply declining portion of the budget for nattional defense is immediately evident. In 1955, 58.1 percent of total outlays went to defense; by 1980 , this proportion had dwindled to 23.4 percent, though the trend has been relatively stable since 1976 .

The rise in benefit payments for individuals as a percent of total outlays, which has more than doubled since 1955 , actually took place during two subperiods. First was the period from 1955 to 1961 , which inchuded two recessions with a weak recovery sandwiched in between. Second was the period from 1968 to 1976 , a period of expanding social programs that also included two recessions.

Net interest held steady at about l percent of total outlays from 1955 to 1974 . Since then, the percentage has been rising slowly but steadily.

Other grants to state and local governments exhibited an upward tread from 1955 to 1973 , but have since leveled off. All other outlays, on the other hand, have varied considerably, rising shaply from 1955 to 1965 , declining until 1974 , then stabilizing in the late 1970s.

In summary, the composition of the budget has undergone a substantial change over the last 25 years. While rational defense used to be far and away the most important function of the federal government, this category has yielded to social programs in the form of benefits for individuals. The sam of these two large program categories has declined as a percent of total outays from 78.5 percent in 1955 to 70.2 percent in 1980 . The slack has been taken up by an increasing proportion of outays channeled to state and local government and paid in interest to the public. 
Chart 2

Federal Budget Outlays as a Percent of Tofal Outlays:1

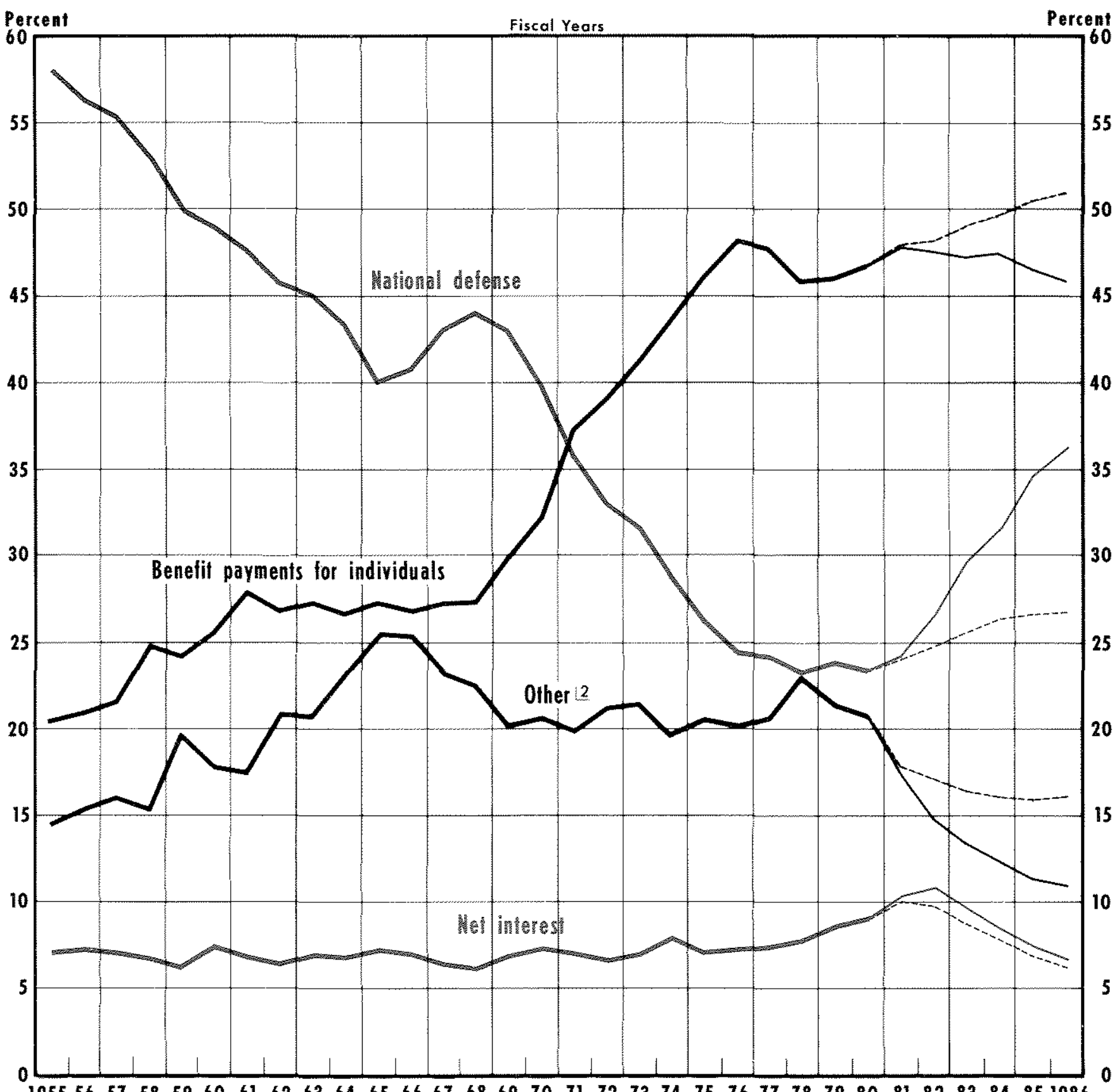

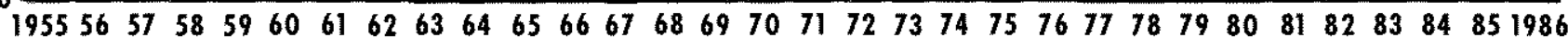

1 Estimates for 1981-1986 are alternative projections: dashed lines are CBO baseline projections and solid lines are administrafion projections from Mid-Session Review of the 1982 Budget (july 1981 ).

2 Other federal operations, plus grants to state and local governments other than benefit payments for individuals. 


\section{BASELINE PROJECTIONS OF FEDERAL SPENDING: $1981-86$}

An evaluation of spending plans for the future requires a baseline for comparison, namely, a course that federal spending would follow were there no changes in spending policies. A set of such baseline projections has been prepared by the CBO and is presented here.

\section{CBO's Economic Assumptions}

The projections assume that expenditures are based on spending policies and laws in effect as of December 1980 . With respect to so-called entitlement programs (social security, Medicaid, veterans pensions, federal employee retirement, etc.), it is assumed that future spending will respond to economic and demographic changes in the same way as in the past.

Since the remaining portion of federal outlays are discretionary, that is, they depend on anntal appropriations, special assumptions are required. The general assumption is that programs in effect in December 1980 will continue into the future with increases in outlays a reflection of the rate of inflation. Thus, inflation rates are a critical part of the economic assumptions. In the case of national defense, CBO's baseline projections also include an allowance for programmatic changes. Specifically, projections of outlays are consistent with a defense force and investment program that is implied by congressional action through December 1980.

The future course of federal outlays thus depends on the underlying economic assumptions. The $\mathrm{CBO}^{2}$ s economic assumptions are summarized in table 2 . With about 30 percent of federal spending directly indexed for inflation, the inflation assumptions bear considerable weight. In addition, the costs of many other programs are based on the assumption that congressional actions will provide the funding to keep the programs apace with inflation. There are also programs like unemployment compensation and food stamps that depend on the assumptions made about unemployment. Net interest paid depends on interest rate projections as well as future deficits.

In general, the $\mathrm{CBO}^{\prime}$ 's economic assumptions are taken as given for the baseline budget projections. There is no allowance for the feedback of fiscal actions to the economy. For example, CBO notes that the projected surplus in the baseline budget would be inconsistent with the underlying economic assumptions. In other words, their economic assumptions do not represent the output of a fullfledged econometric model.

\section{CBO's Baseline Projections}

Chart 1 summarizes the baseline projections as a percent of GNP for 1981-86. The momentum of total outlays as well as high inflation projections in the near term indicate a slight rise in total outlays in 1981-82 relative to 1980 . After 1982, total outlays decline relative to GNP. There are several reasons for this. First, the baseline projections do not provide for real growth in a number of program areas, while the GNP projections include substantial increases in real GNP. Second, with unemployment assumed to decline, programs tied to the unemployment rate grow more slowly. Similarly, net interest outlays decline, assuming declines in interest rates and in the deficit. ${ }^{5}$

The national defense component of federal outlays is assumed to hold fairly constant under the baseline assumptions, implying real growth in defense outlays. The major reason for an increase in real tems is an increase in the cost of strategic forces, namely, the inclusion of funding for the MX missile and a new manned bomber. Consequently, based on programmatic changes implied by congressional action through December 1980 , defense outlays would be 5.2 percent of GNP in 1986 , little changed from 5.3 percent in 1980 .

Benefit payments for individuals are projected to rise in 1981-82 relative to GNP, but fall slowly from 1983-86. The proportion stays high relative to GNP because so many of the benefit programs are indexed to inflation. "The most important of these are social security benefits, railroad retirement benefits, supplemental security income, veterans' pensions, and civil service retirement benefits. Other programs, like food stamps and child nutrition, unemployment compensation, and Medicare and Medicaid, are indirectly tied to inflation. But in addition to keeping pace with inflation, benefit payments for individuals rise faster than the price level because the number of

\footnotetext{
It should be noted that the CBO's baseline estimate of net izterest does not reflect fully the surplus/deficit estimates implied by their full set of baseline estimates of revenues and expenditures. For purposes of their baselme spending projections, the budget was asstmed to be balanced beginning in 1984, and the substantial sumplases estimated after 1984 were not assumed to be applied to reductions in the public debt.
} 


\section{Table 2}

\section{CBO Economic Assumptions (calendar years)}

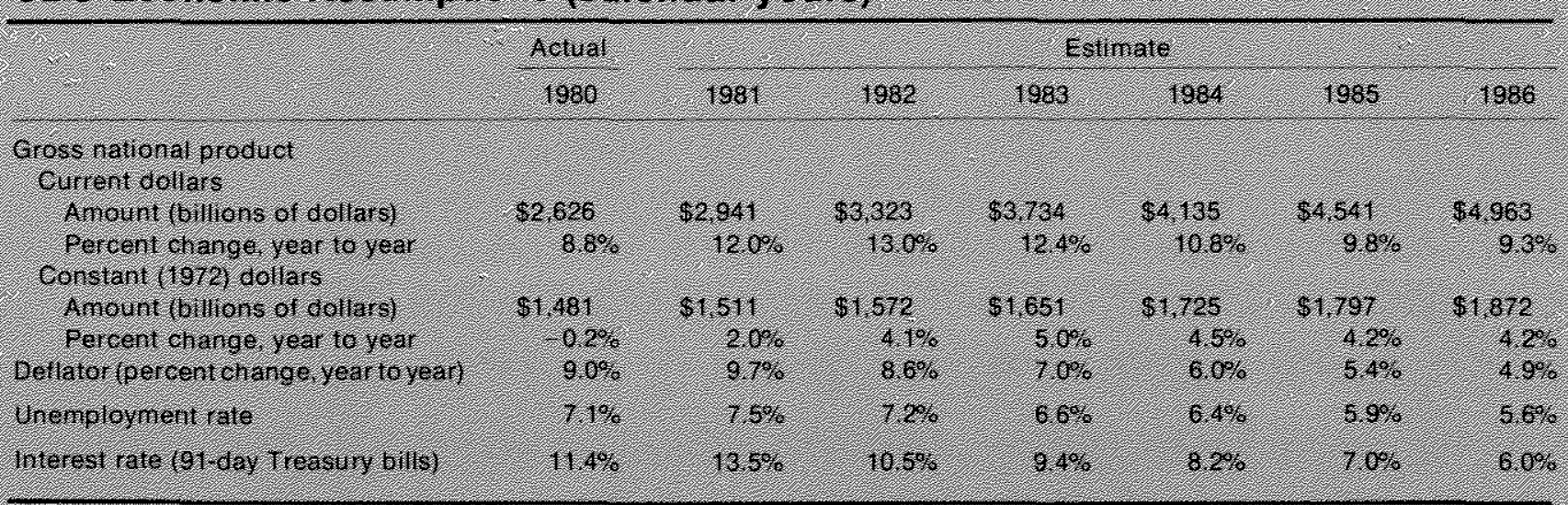

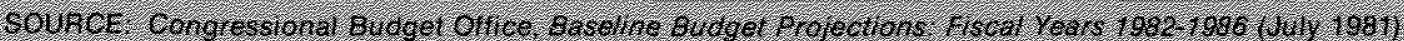

retirees and disabled persons grows. Baseline projections indicate benefit payments would be 10 percent of GNP in 1986 compared with 10.6 percent in 1980 .

Other grants to state and local governments are projected to decline to 1.5 percent of GNP in 1986 compared with 2.2 percent in 1980 . This would be a decline in real terms and is accounted for in part by statutory ceilings on social service grants and general revenue sharing. Furthermore, community development grants are projected to rise little under existing law.

Baseline projections for net interest indicate a substantial decline relative to GNP, from 2.0 percent in 1980 to 1.2 percent in 1986 . This projection is a direct result of the economic assumption that interest rates will decline throughout the period and that the budget will be balanced by 1984 .

The catch-all category of "all other" is also projected to decline - from 2.4 percent of GNP in 1980 to 1.7 percent in 1986 . Implicit in the projection is that "all other" outlays will keep pace with inflation though they will show no real growth.

The implications of the baseline projections for the composition of federal outlays are summarized in chart 2. Benefit payments are slated to stay high, rising somewhat relative to the total. Benefit payments, 46.8 percent of total outlays in 1980 , are projected to rise to 51.0 percent based on existing law.
The future pattern of national defense relative to total outlays also is one of steady increase. National defense, which was 23.4 percent of total outlays in 1980 , is projected to rise to 26.7 percent in 1986 assuming the expansion of strategic forces.

With the sum of benefit payments and national defense rising from 70.2 percent of total outlays in 1980 to 77.7 percent in 1986 , there is a substantially lesser proportion of the total going toward the remaining three categories. These categories share the decline about equally, dropping about 2 or 3 percentage points from 1980 to 1986.

\section{ADMINISTRATION PROJECTIONS OF FEDERAL SPENDING: $1981-86$}

The new administration announced a program of spending cuts shortly after taking office early this year. These proposals were first presented in March and subsequently revised in the mid-session review of the budget in July. ${ }^{6}$ Controversy surrounding these proposals probably will continue as the administration works with Congress in reviewing these proposals. For the purposes of this article, the estimates of the administration as of July 15,1981 , are used because they are the most current set of officially published estimates. The final results will differ from those presented here, but the July proposals are representative of the administration's plan.

6Office of Mamagement and Budget, Fisct Year 1982 Budget Pevisions (March 1981) and Mid-Session Review of the 1982 Budret Uuly 15, 1981). 


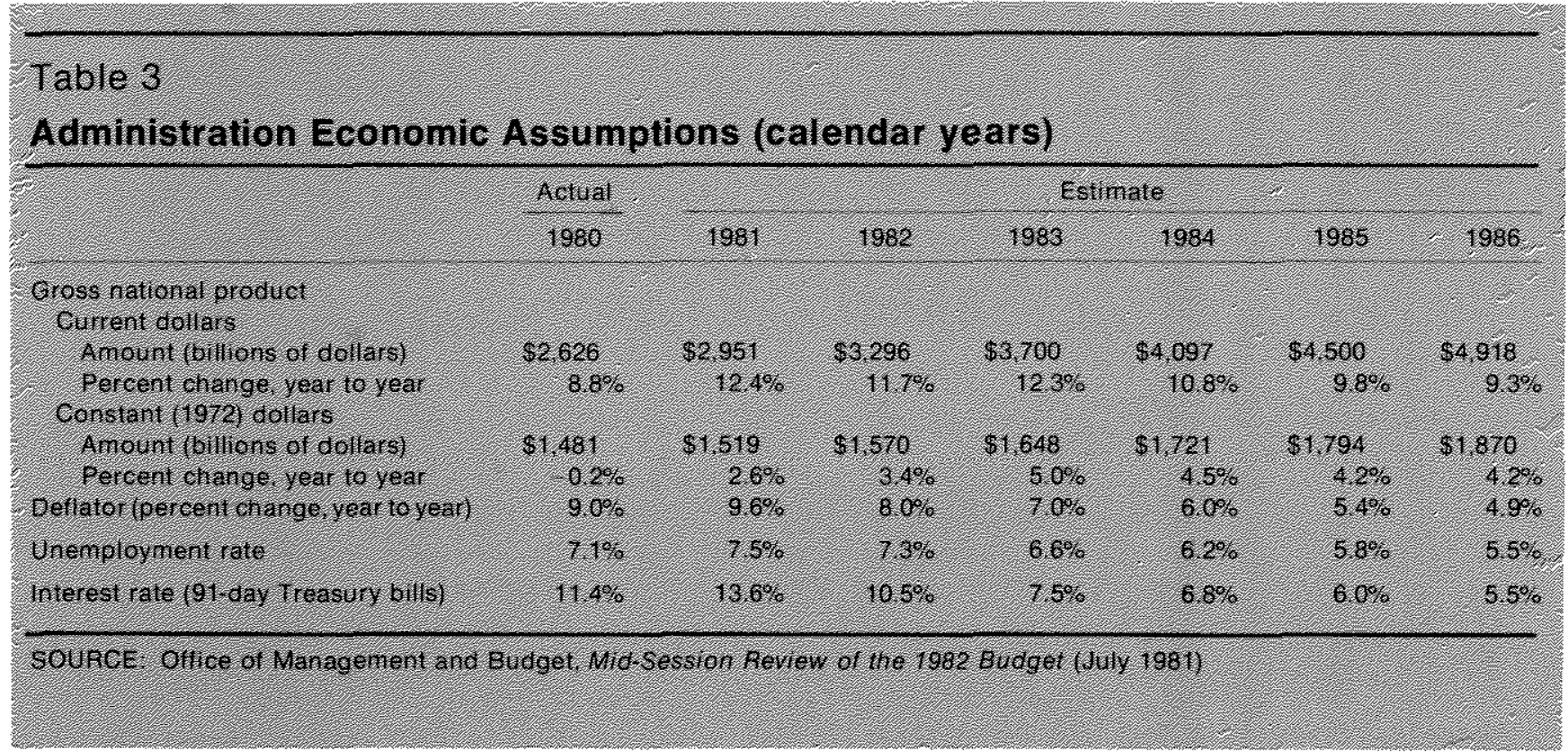

\section{Economic Assumptions}

As alluded to above, any spending proposals depend on the particular economic assumptions that are made. Table 3 summarizes the administration's economic assumptions as presented in the mid. session review of the budget on July 15 . These assumptions are similar to CBO's in that they are called assumptions, not projections. The administration goes slightly further, however, saying that these assumptions are projections of the trend of economic performance expected under the administration's new policy. So, even though these assumptions do not appear to be based on a consistently estimated econometric model, they do allow for the feedback of economic policies to the economic assumptions, albeit in an informal way.

A comparison of table 3 with the $\mathrm{CBO}^{\text {'s }}$ assumptions in table 2 indicates that the general contours of the economic projections are similar. The course of GNP and its distribution between prices and output is essentially the same for the administration as for the CBO. For example, the difference in the average annual rate of increase of nominal GNP over the 1980-86 period is only 0.1 percentage point 11.1 percent for the administration compared with 11.2 percent for the $\mathrm{CBO}$. The principal difference in the two sets of economic assumptions is with respect to interest rates; the administration assumes Treasury bills will decline to 5.5 percent in 1986 compared with 6.0 percent for the CBO.

\section{Administration Spending Projections}

In general, the administration plans to reduce total outlays relative to GNP from 22.6 percent in 1980 to 18,6 percent in 1986. In comparison, the CBO projects total outlays to be 19.6 percent of GNP in 1986. In 1986 dollars, this difference amounts to $\$ 55$ billion (see table 4 ); in other words, the administration is proposing that total outlays be reduced by $\$ 55$ billion from what they would otherwise be, based on existing law.

The major departure of the administration's plan from the baseline projections is that it plans a sharp increase in national defense spending even as a percent of GNP. The administration's plan calls for defense spending to be 6.7 percent of GNP in 1986 compared with 5.2 percent for the baseline projections. This would be the largest proportion of GNP diverted to defense since 1972.

With total outlays projected to decline relative to GNP and national defense projected to increase, non-defense must decline sharply as a percent of GNP. The largest component of non-defense outlays - benefit payments for individuals - is projected at 8.5 percent of GNP in 1986 compared with a baseline figure of 10.0 percent. In 1986 dollars, this is a reduction of $\$ 73.1$ billion, or 15 percent. Included in the administration's reduction in benefit payments is the cutback in social security benefits that generated considerable controversy last spring and subsequently was withdrawn pending the recommenda- 


\section{Table 4}

\section{Federal Spending Projections: Administration vs, Baseline (billions of dollars)}

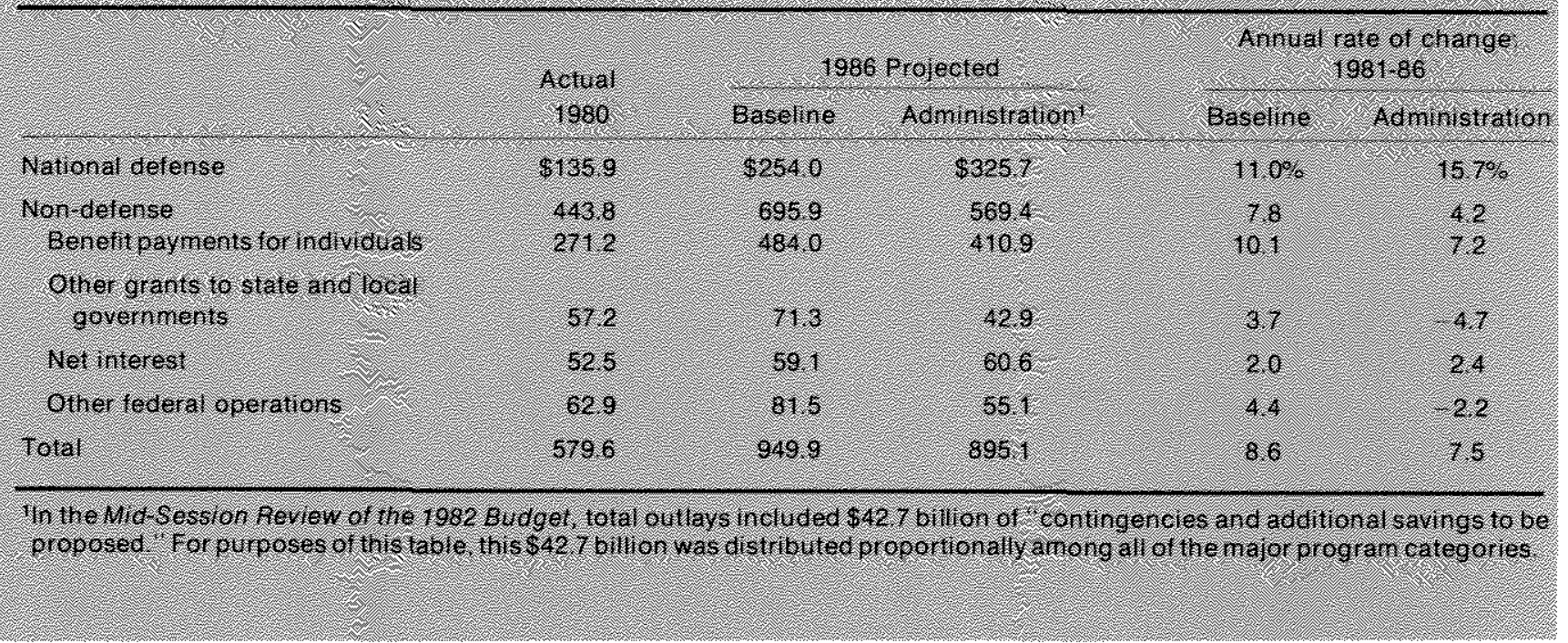

tions of a new commission, ${ }^{7}$ Although social security benefits as a percent of total benefit payments to persons would rise slightly, such benefits as a percent of GNP would drop from 4.5 percent in 1980 to 4.1 percent in 1986 .

Of the remaining program categories, only net interest is close to the baseline projection for 1986 . As a pereent of GNP, net interest is projected at 1.3 percent of GNP, essentially the same as the 1.2 percent baseline projection. ${ }^{8}$ The other two remaining categories are sharply below the baseline projections. All other grants to state and local governments are projected by the administration at 0.9 percent of GNP compared with 1.5 percent for the baseline projection, a cutback of $\$ 28$ billion in 1986 dollars, or

${ }^{2}$ The set of proposals affecting social security included the following:

(1) Reducing the welfare-oriented elements that duplicate other programs;

(2) Relating aisability benefits more closely to a person's work history and medical conditions;

(3) Reducing the oppotunty for "windfull" benefits;

(4) Shifting the effective date for paring the automatic cost-ofliving increases from July to October;

(5) Fneoumaging workers to stay on the job at lenst until the traditional retirement age of 65 ;

(6) Lowering future replacement rates - the initial benefit as compared with recent preretrement eamings.

Even though the administration assumes that interest mates will be lower by 1986 , its estimate of net interest exceds the baseline projection because its deficit estimates are larger (or surpluses are smaller) during the projection period. The retson for this is that the baseline revenue profections are based on tax laws as of December 1980 , whereas the administration's plan includes the tax cut.
40 percent, which would bring this category back to 1963 levels. Similarly with the "all other" category, the administration's plan calls for all other outlays to be scaled back to 1.1 percent of GNP compared with 1.7 percent for the baseline projection. This would be a reduction of $\$ 26.4$ billion in 1986 dollars, or 32 percent, and would bring this category lower than ever recorded in the 1955-80 period.

The scope of the administration's program is dramatized even more when one examines the program categories relative to total outlays. In order to reduce total outlays by $\$ 55$ billion in 1986 relative to baseline projections and at the same time increase national defense by $\$ 72$ billion, the administration must reduce non-defense outlays by $\$ 126$ billion. Furthermore, with an administration net interest projection of $\$ 2$ billion greater than the baseline estimate, the remaining categories must be reduced by $\$ 128$ billion. Given the baseline projection of $\$ 637$ billion for non-defense exchuding net interest, a $\$ 128$ billion cutback translates into a 20 percent reduction from what they would otherwise be.

As a percent of total outlays, the national defense projection amounts to 36.4 percent compared with 26.7 percent for the baseline projection. To achieve such a goal would give defense an importance in the budget not realized since 1970 .

The scaling back of benefit payments would reduce such payments as a percent of the total to 45.9 percent compared with 50.9 percent for the baseline. 
On this basis, this would be the lowest share for this category of spending since 1974 .

With net interest being projected at 6.8 percent of total outlays compared with 6.2 percent for the baseline, the other reductions come from the two remaining catch-all categories. All other grants to state and local governments would be reduced to 4.8 percent of the budget compared with 7.5 percent for the baseline. This would be the smallest proportion of the budget for this category since 1963.

The final "all other" category, according to administration projections, would be reduced to 6.2 percent of total outlays compared with an 8.6 percent baseline projection. This would be lower than any other year in the 1955-80 period.

\section{SUMMARY AND CONCLUSIONS}

The administration has embarked on a budget program designed to reduce the size of government in the U.S. economy. At the same time, they propose to alter greatly the composition of the budget. Over the last 25 years, federal outlays grew more rapidly than the nation's GNP. At the same time, the composition of these outlays shifted toward greater non-defense spending, particularly benefit payments for individuals.

In planning for the next five or six years, the administration has set forth proposals designed to alter past trends. One goal is to reduce the overall growth of federal outlays relative to GNP. According to the administration's plan, outlays will be 18.6 percent of GNP in 1986, down from 22.6 percent in 1980 , reducing the relative size of government to its lowest level since 1966. Existing law indicates that outlays are scheduled to be reduced relative to GNP anyway, but to 19.6 percent rather than 18.6 percent.

Slowing the momentum of government spending is an ambitious goal, but the way in which the administration proposes to achieve it makes the task all the more difficult. By announcing a goal of accelerating defense spending while slowing the growth of total outlays, the administration implies that sharp cutbacks are required for non-defense spending relative to baseline projections. The scaling back of non-defense programs other than net interest amounts to 20 percent compared with baseline prow jections. Relative to baseline projections, this nondefense cutback is distributed as a 15 percent reduction in benefit payments for individuals, 40 percent for other grants to state and local govemments, and 32 percent for the all other category. 